\title{
Arkadiusz Lorenc
}

Uniwersytet Łódzki

\section{Dlaczego śmieszą nas z założenia nieśmieszne żarty? - kilka uwag na temat krótkich żartów publikowanych na stronie suchary.com}

\section{Wstęp}

Internet przestaje powoli być rozumiany jako medium zapewniające jego użytkownikom dostęp do informacji, stając się platformą umożliwiającą aktywne komunikowanie się internautów [Księżopolska 2007: 171]. Coraz częściej użytkownicy Sieci poszukują w niej rozrywki. Z tego powodu niesłabnącą popularnością cieszą się strony internetowe umożliwiające publikowanie memów internetowych (często o charakterze humorystycznym) czy specjalizujące się w udostępnianiu żartów lub umożliwiające ich udostępnianie swoim użytkownikom.

Jedną ze stron internetowych, na której publikowane są żarty, jest portal suchary.com. Właściciele portalu umożliwiają jego użytkownikom dodawanie własnych tekstów. Procedura publikowania krótkich żartów na stronie suchary.com jest nadzorowana - aby nadzór ten przebiegał w sposób obiektywny, właściciele portalu opracowali krótki, złożony zaledwie z sześciu punktów regulamin. Informują w nim, że każdy żart dodawany przez użytkowników portalu jest sprawdzany i „poprawiany pod względem poprawności językowej” przez moderatorów strony. Ostatni punkt regulaminu zamieszonego na stronie suchary.com zdaje się być raczej mottem portalu 
niż istotną częścią próby sformalizowania zasad publikowania tekstów panujących na tej stronie internetowej. Brzmi bowiem: „Niech suchar będzie z Tobą". Jest to oczywista parafraza słów jednego z bohaterów słynnego filmu Gwiezdne Wojny. Zabieg ten ma na celu najprawdopodobniej złagodzenie wymowy regulaminu, stanowiąc tym samym element koherentny z pozostałą częścią portalu.

Warto również przyjrzeć się nazwie strony internetowej, która dostarczyła mi korpusu do badań nad zabiegami językowymi wywołującymi efekt humorystyczny. Leksem „suchar” jest bowiem słowem używanym w znaczeniu „rodzaj żartu” od niedawna, występuje przede wszystkim w środowisku internetowym. Internauci przyjęli używanie tego słowa na określenie na ogół krótkich, lapidarnych (i przede wszystkim tym różniących się od tradycyjnych dowcipów, które określić by można mianem narracyjnych) żartów. Należy również dodać, że przyjęło się rozumieć pod pojęciem „suchara” żart, który z założenia może nie być śmieszny. Pragnę jednak zaznaczyć explicite, że celem artykułu jest opis wybranych zabiegów językowych mających potencjał wywoływania efektu humorystycznego, nie zaś refleksja nad cechami tego gatunku internetowego.

Warto zaznaczyć, że zabiegi językowe mające za zadanie wywołanie efektu humorystycznego, zastosowane w tego typu zwięzłych tekstach nie zawsze są mocno wyeksponowane; niekiedy odbiorca żartu musi nawet sięgnąć do znajomości języków obcych, najczęściej języka angielskiego, by właściwie rozszyfrować znaczenie użytych przez autora tekstu słów.

Z metodologicznego punktu widzenia warto zaznaczyć, że dokonana przeze mnie analiza obejmuje około tysiąca wybranych tekstów żartów opublikowanych na stronie internetowej suchary.com w okresie od 4 lipca 2011 roku do 24 lutego 2014 roku. Nie podejmuję jednak próby usystematyzowania (stworzenia klasyfikacji) wszystkich przeanalizowanych tekstów. 


\section{Zabiegi językowe wywołujące efekt humorystyczny, zastosowane $\boldsymbol{w}$ analizowanych żartach}

Na uwagę zasługuje z pewnością różnorodność zabiegów językowych stosowanych przez autorów analizowanych żartów. Bardzo często odwołują się oni do znajomości języków obcych, przede wszystkim języka angielskiego, by na tej bazie budować neologizmy, będące jednocześnie homonimami w stosunku do istniejących w polszczyźnie słów. Posługują się m.in. innowacją językową, homofonią i wieloma innymi zabiegami, których krótką systematykę wraz z przykładami ilustrującymi użycie przedstawiam poniżej.

2. 1. Homonimia, homofonia i zjawiska im podobne o potencjale wywoływania efektu humorystycznego

Uważam za bezwzględnie konieczne odwołanie do sposobów definiowania pojęcia homonimii $w$ literaturze językoznawczej. Pojęcie homonimia wywodzi się od greckiego homōnymos, oznaczającego „wieloznaczność”. Jak podaje Wojan, „ogólnie rzecz ujmując, homonimia polega na tym, że dwie (lub więcej) identyczne pod względem fonetycznym i graficznym jednostki językowe wyrażają odmienne treści znaczeniowe" [Wojan 2010: 138]. Trzeba jednak powiedzieć, że $w$ literaturze przedmiotu istnieje wiele definicji tego pojęcia. W zacytowanym wyżej ujęciu wyraźnie zaznaczono, że kryterium decydującym o tym, czy dwa leksemy mogą zostać uznane za homonimy, jest nie tylko kryterium zapisu graficznego, lecz także kryterium fonetyczne. Wielu autorów unika jednak rozróżniania między tymi kryteriami. I tak na przykład według Encyklopedii wiedzy o języku polskim pod red. Urbańczyka (Wrocław 1978) homonimia „polega na wyrażaniu różnych znaczeń za pomocą identycznej formy językowej". Słownik języka polskiego pod red. Szymczaka (PWN, Warszawa 1999) podaje tymczasem, że „homonimia to jednakowe brzmienie dwóch wyrazów mających różne znaczenia" [oba cyt. za Wojan 2010: 139]. 
Należy również wspomnieć o istnieniu homofonii, która tym różni się od homonimii, że dotyczy dwóch lub więcej leksemów identycznych pod względem realizacji fonetycznej, lecz różniących się zapisem. Stosowanie homofonii należy do częstych zabiegów językowych, którymi posługują się autorzy analizowanych żartów; nie jest jednak tak popularne jak stosowanie homonimii.

Wśród analizowanych żartów, których komizm zbudowany jest dzięki zastosowaniu homonimii, za prototypowe możemy uznać następujące przykłady':

(1) Rozmawiają ze sobą dwa koguty:

- Ty chodzisz z tą kurą tak na serio, czy dla jaj?

(2) Wchodzi kogut do łazienki, a tam zakręcone kurki.

(3) Co robi terrorysta-nauczyciel, kiedy dzieci źle się zachowują?

- Rozsadza je ${ }^{2}$.

W przykładzie (1) okolicznik celu „dla jaj” może być rozumiany dwuznacznie (warunkuje to jego dystrybucja); kontekst (rozmowa dwóch kogutów) umożliwia interpretację wyrażenia homonimicznego jako „w celu złożenia przez kurę jaj”. Z drugiej jednak strony $w$ języku polskim ( $w$ jego potocznej odmianie) frazeologizm „dla jaj” oznacza „dla żartu, dla popisu” [Kłosińska, Sobol, Stankiewicz 2007: 147]. Dopasowanie drugiego z wymienionych znaczeń ma $w$ tym przypadku uzasadnienie $w$ postaci umieszczenia $w$ żarcie opozycyjnego wyrażenia „na serio”. Opozycja ta jest oczywista, przez co potęguje wywołany efekt humorystyczny.

„Zakręcone kurki”, które znajdziemy w drugim z przytoczonych tekstów (2) również mogą być interpretowane dwojako. W tym przypadku także warunkuje to dystrybucja wyrażenia i kontekst

1 Wszystkie zacytowane w pracy żarty pochodzą ze strony internetowej [http:// www.suchary.com].

2 Posłużyłem się pogrubieniem $w$ celu graficznego wyeksponowania homonimów zawartych w żartach. 
nakreślony zwięźle $w$ jednym zdaniu, stanowiącym całą treść żartu. Aby dobitnie pokazać, na czym polegał koncept autora żartu, przeanalizuję oddzielnie imiesłów przymiotnikowy bierny „zakręcone" i rzeczownik „kurki”.

Zgodnie z definicją podaną w Słowniku języka polskiego pod red. M. Szymczaka „zakręcić” (czasownik, od którego utworzono imiesłów użyty w żarcie) oznacza „zamknąć coś za pomocą nakrętki; kręcąc docisnąć, zamknąć coś" [Szymczak 1988: 917]. Wśród przykładów ilustrujących użycie czasownika "zakręcić" autor słownika podaje „zakręcić kurek od gazu” [tamże]. Przytaczam ten przykład celowo - pokazuje on, że omawiany czasownik występuje w związku z rzeczownikiem „kurek”, który również pojawił się $w$ analizowanym żarcie (2). Należy jednak zaznaczyć, że $w$ języku potocznym imiesłów ten oznacza „szalony lub niesamowity”.

Jak czytamy w Słowniku języka polskiego pod red. M. Szymczaka, „kurek” to „element zamykający zaworu kurkowego, obracalny dokoła własnej osi czop z odpowiednim układem kanałów" [Szymczak 1988: 1089]. Autor zaznacza, że w mianowniku liczby mnogiej rzeczownik przyjmuje końcówkę -rki - tymczasem końcówka fleksyjna liczby mnogiej deminutivum rzeczownika „kura” - „kurka”, przyjmuje końcówkę fleksyjną -i, co w rezultacie wywołuje efekt homonimii (kurki-kurki).

Podsumowując zatem krótko rozważania nad żartem (2), należy stwierdzić, że efekt humorystyczny zbudowany jest tu przede wszystkim na dwuznaczności homonimicznego wyrażenia „zakręcone kurki”, oznaczającego z jednej strony tyle, co „szalone kury” (i $w$ ten sposób koherentnego $w$ stosunku do agensa), a $z$ drugiej strony - „zamknięte zawory kurkowe” (nawiązującego na płaszczyźnie semantycznej do okolicznika miejsca).

W przypadku żartu ostatniego (3) mamy do czynienia z homonimią czasownika „rozsadzać”, który może oznaczać „rozdzielić, posadzić $w$ pewnej odległości od siebie osoby siedzące uprzednio razem” [Szymczak 1988: 117], lecz także „sprawić, żeby coś się rozerwało, eksplodowało, wysadzić w powietrze" [Szymczak 1988: 917]. Przyjmując zaproponowane przez Słownik języka polskiego pod 
red. M. Szymczaka definicje za oczywiste, należy uznać, że pierwszy człon rzeczownika określającego podmiot (terrorysta-nauczyciel) odnosi się do drugiej, zaś drugi człon - do pierwszej z podanych wyżej definicji.

W tym momencie pragnę zauważyć, że zabiegi wywołujące efekt humorystyczny są często zabiegami kompleksowymi, współwystępującymi i potęgującymi wzajemnie swoją moc. W dwóch z przytoczonych wyżej przypadków, (1) oraz (2), nie bez znaczenia jest na przykład sama antropomorfizacja zwierząt. $Z$ reguły jednak to jedno, konkretne działanie autora dominuje, determinując wymowę tekstu; pragnę jednak zaznaczyć, że ilekroć w dalszej części artykułu mowa będzie o „zabiegu posiadającym potencjał wywoływania efektu humorystycznego", należy rozumieć przez to ów efekt dominujący w określonym tekście.

Należy podkreślić, że nie każdy przypadek homonimii $w$ analizowanych przeze mnie żartach był tak oczywisty, jak try poprzednie. Na poparcie mojego stwierdzenia podam jeden tylko przykład:

(4) Jak się nazywa nauka o mrówkach?

\section{- Antologia.}

Słownik języka polskiego pod red. M. Szymczaka podaje, że antologia to „zbiór utworów lub ich fragmentów powiązanych wspólną tematyką albo należących do jednego gatunku literackiego, do jednego okresu itp. (...)" [Szymczak 1988: 59]. Nie odnotowano innego znaczenia tego słowa. A zatem dlaczego możemy mówić w tym przypadku o homonimii? Czy mamy z nią do czynienia?

Aby zrozumieć ten zabieg językowy, należy sięgnąć do znajomości języka angielskiego, w którym ant oznacza mrówkę. Autor dodając do tego leksemu interfiks -o- oraz sufiks -logia (od gr. logos - słowo) stworzył neologizm (bo nie neosemantyzm) ${ }^{3}$. Słowo

3 Z neosemantyzmem mielibyśmy do czynienia, gdyby autor nadał nowe znaczenie istniejącemu wyrazowi, nie zaś stworzył wyraz nowy - zgodnie z regułami słowotwórstwa, które jesteśmy w stanie zrekonstruować - brzmiący identycznie jak istniejący już leksem. 
„antologia” w kontekście tego żartu nie oznacza zatem „zbioru utworów literackich" (to użycie byłoby niezrozumiałe, niekoherentne $w$ stosunku do treści żartu, a tym samym czyniące go niezrozumiałym), lecz naukę o mrówkach, nazywaną prawidłowo myrmekologią.

W tym prypadku możemy zatem mówić o homonimii, choć mamy do czynienia z jej przypadkiem szczególnym, gdzie jeden $z$ homonimów jest neologizmem utworzonym w sposób sztuczny na potrzeby konkretnego przypadku użycia.

Należy poczynić rozważania nad tym, czy przytoczony żart (4) nie jest tłumaczeniem - kalką z języka angielskiego. Za takim stwierdzeniem przemawiałby fakt, że dla pełnego zrozumienia znaczenia tekstu jego adresat musi wykazać się znajomością tego języka. Dla osoby posługującej się językiem angielskim jako ojczystym dostrzeżenie związku między „nauką o mrówkach” wzmiankowaną w pierwszej części tekstu i słowem *antology (bo prawdopodobnie tak musiałaby wyglądać jego wersja angielska) byłoby o wiele prostsze. Z drugiej strony, na gruncie języka angielskiego mielibyśmy w tym przypadku do czynienia raczej z homofonią niż z homonimią - słowo antologia tłumaczone jest bowiem na angielski jako anthology, nie zaś *antology. Ten drugi leksem w języku angielskim $w$ ogóle nie istnieje ${ }^{4}$. A zatem nawet jeśli mówilibyśmy o homofonii w tym przypadku, to byłaby ona również przypadkiem szczególnym ze względu na to, że jeden z homofonów nadal pozostawałby neologizmem.

Homofonia również jest częstym zabiegiem stosowanym przez autorów żartów publikowanych na stronie internetowej suchary. com. Przypomnijmy, że homofonia (z gr. homophōnía „jednogłośność; jednorodność dźwięku”) to (zgodnie z definicją Encyklopedii językoznawstwa ogólnego pod red. K. Polańskiego) „identyczność fonetyczna dwóch lub więcej form językowych (wyrazów), które

4 Słowo to nie jest odnotowane $w$ żadnym ze słowników określanych wspólnym mianem Orford Dictionaries, a dostępnych pod adresem: http:// www.orforddictionaries.com (dostęp 08.03.2014). 
mogą się różnić pisownią, etymologią i znaczeniem, np. może - morze" [cyt. za Wojan 2010: 146]. Wśród przykładów żartów zbudowanych w oparciu o homofonię znajdziemy m.in.:

(5) O jakim piwie myśli kot?

\section{- Okocim.}

(6) Jaki jest poziom trudności na wyścigach psów?

- Poziom hart.

W żarcie (5) wykorzystano nazwę własną znanej w Polsce marki piwa - Okocim. Kiedy żart przekazywany jest w formie ustnej, efekt homofonii jest wyraźniejszy. W przypadku zapisu graficznego nadal jednak można go rozpoznać.

W przypadku żartu (6) autor posłużył się słowem „hart”. Aby zrozumieć sens tego żartu ponownie należy sięgnąć do znajomości języka angielskiego. Słowo podobne do użytego, hard, oznacza po angielsku m.in. requiring a great deal of endurance or effort ${ }^{5}$. Jest także niekiedy używane w polszczyźnie, głównie w odniesieniu do poziomów trudności $w$ grach komputerowych. Wówczas zgodnie z zasadą mówiącą, że w polszczyźnie spółgłoski dźwięczne ulegają w wygłosie ubezdźwięcznieniu [Bąk 1987: 93] - leksem ten realizowany jest jako [xart]. W ten sam sposób realizowany jest leksem „chart”, oznaczający rasę psa. Autor stworzył zatem wspólną płaszczyznę, elastyczne połączenie uzasadniające użycie wyrażenia „poziom hart” w kontekście przytoczonego żartu (6).

Pozostaje rozpatrzyć wyrażenie „poziom hart” z punktu widzenia zapisu graficznego (paradoksalnie, bo przedmiotem refleksji są teraz homofony). Zastanawiające jest, dlaczego autor wybrał wariant zapisu „hart” - to słowo (zapisywane w podany sposób) nie istnieje $w$ języku polskim, $w$ angielskim oznacza zaś jelenia, czyli nie ma związku z kontekstem. Można sądzić, zakładając

5 Definicja na podstawie Orford English Dictionary, dostępny w Internecie, http://www.orforddictionaries.com/definition/english/hard?q=hard [dostęp 08.03.2014]. 
optymistycznie, że autor próbował upodobnić wyraz „chart” do angielskiego hard. Można również uznać, że popełnił błąd ortograficzny. Trudno orzec jednoznacznie, dlaczego akurat z takim wariantem zapisu mamy do czynienia. O błędach i innowacjach w żartach opublikowanych na stronie internetowej suchary.com piszę kilka słów w dalszej części artykułu.

W analizowanych tekstach można znaleźć również zabiegi pozornie przypominające homofonię, $w$ istocie jednak nie spełniające jej warunków, przynajmniej według przytoczonej wcześniej definicji. Por.:

(7) Co robią lekarze $w$ kuchni?

- Leczo.

(8) Jakie jest ulubione ciasto szefa?

- Tyrajmisiu.

(9) Jak się nazywa tur po obfitym posiłku?

- City tour.

W każdym z przytoczonych powyżej tekstów: (7), (8), oraz (9) pojawia się wyrażenie, które brzmi podobnie do istniejącego w polszczyźnie innego wyrażenia. I tak analogicznie: „leczo” ma przypominać czasownik „leczyć” w 1. os. l. mn. cz. teraź. (por. leczą) ${ }^{6}$; „Tyrajmisiu” to oczywista analogia do nazwy popularnego deseru - tiramisu.

Ostatni przykład jest nieco inny od pozostałych. Ponownie, do jego zrozumienia wymagana jest znajomość przynajmniej zasad wymowy w języku angielskim. Z pewnością można jednak powiedzieć, że widać podobieństwo między ['siti toə] oraz ['siti tur], nawet jeśli nie jest ono uderzające. Autorzy zdecydowali się zatem użyć wyrazów lub frazemów nie będących homofonami, lecz wyraźnie przypominających słowa, których można by oczekiwać w kontekście cytowanych tekstów.

6 Należy zaznaczyć, że w niektórych gwarach małopolskich mamy do czynienia z denazalizacją wygłosowego -ą, które realizowane jest wówczas jak [o]. 
Homonimia i homofonia są zabiegami językowymi, po które chętnie sięgali autorzy tekstów analizowanych $w$ niniejszym artykule. Należy jednak zaznaczyć, że aby wywołać określony efekt, autorzy musieli wykazać się nie tylko dużym stopniem kreatywności, lecz także znajomością (przynajmniej podstawową) zasad słowotwórstwa polskiego czy fonetyki i leksyki języka angielskiego - tym samym muszą wykazać się odbiorcy żartów, by rozpoznać ich prawdziwy sens.

Z oczywistymi przypadkami homonimii i homofonii zestawiłem przypadki jedynie przypominające te zjawiska. Pragnę zaprezentować $w$ ten sposób różnorodność zabiegów językowych, jakie spotkać można, analizując żarty zamieszczone na stronie internetowej suchary.com.

\subsection{Błąd czy innowacja?}

Bardzo trudno niekiedy właściwie uchwycić różnicę między błędem językowym a innowacją. Można ogólnie uznać, że innowacja językowa to takie odchylenie od normy, które zbliży język do języka doskonałego - czyli takiego, który będzie w stanie zaspokoić wszystkie potrzeby komunikacyjne jego użytkowników, jednocześnie wymagając od nich jak najmniejszego wysiłku [Kurkowska 1986: 22]. Innymi słowy zatem, innowacja tym różni się od błędu, że w przeciwieństwie do niego jest zmianą uzasadnioną funkcjonalnie [Kurkowska 1986: 21].

W przypadku niektórych z analizowanych żartów, w których mamy do czynienia na przykład z nieprawidłowym zapisem graficznym, bardzo trudno orzec jednoznacznie, z którym spośród wyżej wymienionych zjawisk językowych mamy do czynienia. Przytoczmy ponownie przykład (6):

(6) Jaki jest poziom trudności na wyścigach psów?

- Poziom hart. 
Jak zaznaczyłem wcześniej, konsternację może budzić zapis słowa „hart”. Zgodnie z zasadami polskiej definicji, mając na myśli rasę psa, autor powinien zdecydować się na zapis „chart”. Gdyby $z$ kolei wybrał wariant angielski (por. analiza homofonii $w$ żarcie (6)), czyli hard, żart mógłby stać się niezrozumiały, pomimo że wygłosowe - $d$ uległoby ubezdźwięcznieniu w wymowie ${ }^{7}$.

Można sądzić, że autor celowo zdecydował się na wybór zapisu „hart”. Wybór którejkolwiek z dwóch podanych wyżej możliwości mógłby zaburzyć sens tekstu, tym samym utrudniając jego odbiór i negatywnie wpływając na siłę efektu humorystycznego.

Błędny zapis ortograficzny istniejących w polszczyźnie słów powoduje niekiedy, że stają się one czytelne $w$ kontekście określonego tekstu. Jako prototypowe przykłady tego typu żartów można podać:

(10) Jak nazywa się opodatkowana wrona?

- Kravat.

(11) Jak nazywa się czapka, która nie należy do Witka?

- Czapka Niewitka.

Oczywiste, że w pierwszym z wyżej przytoczonych żartów (10) autor próbował stworzyć słowo brzmiące podobnie do istniejącego rzeczownika „krawat”, jednak zapisane w odmienny sposób. Wykorzystał neologizm, zbudowany z połączenia onomatopeicznego słowa „kra” ( $w$ ten sposób powszechnie naśladuje się $w$ języku polskim $w$ mowie i piśmie dźwięki wydawane przez wronę) ze słowem „VAT”, oznaczającym tak zwany podatek od wartości dodanej. Jeśli przyjmiemy wersję, że $w$ tekście padł neologizm, nie możemy mówić o popełnieniu przez autora błędu.

W drugim (11) z zacytowanych wyżej żartów autor wyraźnie odwołuje się do frazemu „Czapka Niewidka”. Celowo jednak zapisuje drugie ze słów jako „Niewitka”. Tworzy w ten sposób

7 Należy pamiętać, że analizowane żarty udostępniane są w wersji pisemnej i tę formę traktować trzeba jako obowiązującą. 
dwuznaczność - z jednej strony nawiązuje do znanego wszystkim połączenia wyrazów, z drugiej zaś - do imienia Witek, padającego w pierwszej części żartu.

Podsumowując krótko część poświęconą błędom i innowacjom występującym $w$ analizowanych przeze mnie żartach, podkreślić należy, że na ogół niemożliwe jest wyznaczenie jasnej granicy między błędem a innowacją. Na fakt ten wpływ ma już sama różnorodność zabiegów językowych stosowanych przez autorów, które bardzo często nakładają się na siebie. Przypominam jednak, że celem mojego artykułu jest wskazanie zabiegów dominujących $w$ danym tekście, wpływających bezpośrednio na jego humorystyczny charakter - nie zaś wyeksponowanie wszystkich zależności, które można zauważyć $w$ analizowanych żartach.

\section{Podsumowanie}

W artykule z oczywistych względów nie opisuję wszystkich obecnych $w$ przeanalizowanych przeze mnie żartach zabiegów językowych mających potencjał wywoływania efektu humorystycznego u odbiorcy. Koncentruję się na podaniu przykładów i omówieniu tych zabiegów, które zdecydowanie dominują wśród analizowanych tekstów korpusu. Należą do nich przede wszystkim homonimia oraz homofonia (oraz zjawiska przypominające te zależności leksykalne, lecz nieodpowiadające ich immanentnym cechom). Autorzy posługują się także innowacją językową - dopasowując na przykład pod względem zapisu istniejące $w$ polszczyźnie lub w innych językach słowa na potrzeby konkretnego użycia.

Jak zaznaczyłem wcześniej, na wywołanie efektu humorystycznego w każdym, najkrótszym nawet tekście, składa się bardzo często kilka zabiegów językowych. Aby opisać je wszystkie, trzeba by dokonać kompleksowej analizy tekstów na wielu płaszczyznach - nie tylko na płaszczyźnie semantycznej, ale także morfo-syntaktycznej (co jedynie częściowo poczyniłem w zaprezentowanych wyżej analizach poszczególnych tekstów), fonologicznej czy 
wreszcie stylistycznej. Nie bez znaczenia są też odniesienia do wytworów kultury i sztuki, widoczne w wielu tekstach. Również fakt obecności w niektórych żartach zantropomorfizowanych lub wręcz upersonifikowanych zwierząt określonych gatunków ma znaczenie dla potęgowania efektu humorystycznego.

Warto zwrócić uwagę na fakt, że w wielu z analizowanych tekstów pojawiają się elementy lub nawiązania do języka angielskiego. Teksty kultury obecne $w$ Internecie cechują się tym, że powstają w otoczeniu innych tekstów - często także obcojęzycznych (wynika to z właściwości Sieci). To wzajemne oddziaływanie jest na tyle silne, że staje się widoczne już podczas pierwszego kontaktu z przedmiotem analizy. Język angielski - wszechobecny w Internecie - zaznaczył swoją obecność $w$ tekstach o charakterze żartobliwym, stając się doskonałym narzędziem w kreowaniu efektu humorystycznego.

W niniejszym artykule chciałem pokazać niezwykle dużą różnorodność zabiegów językowych spotykanych $w$ bardzo krótkich, lecz jakże ciekawych tekstach publikowanych na stronie internetowej suchary.com. Jestem jednak świadomy tego, że temat ten nie został jeszcze wyczerpany.

\section{Bibliografia}

Bąk P. [1987], Gramatyka języka polskiego, Wiedza Powszechna, Warszawa.

Księżopolska B. [2007], Flirt komputerowy - sztuka zdobywania partnera, [w:] Kreowanie światów w języku mediów, Janik M. (red.), Wydawnictwo Uniwersytetu Marii Curie-Skłodowskiej, Lublin.

Kurkowska H. [1986], Teoretyczne zagadnienia kultury języka, [w:] Kultura języka polskiego, Zondek J. (red.), PWN, Warszawa.

Skowronek B. [2013], Mediolingwistyka. Wprowadzenie, Wydawnictwo Naukowe Uniwersytetu Pedagogicznego, Kraków.

Słownik języka polskiego [1988], Szymczak M. (red.), PWN, Warszawa.

Wielki słownik frazeologiczny PWN z przysłowiami [2007], Kłosińska A., Sobol E., Stankiewicz A. (oprac.), PWN, Warszawa.

Wojan K. [2010], Wstęp do badań wieloznaczności leksemów w ujęciu kontrastywnym, Wydawnictwo Uniwersytetu Gdańskiego, Gdańsk. 